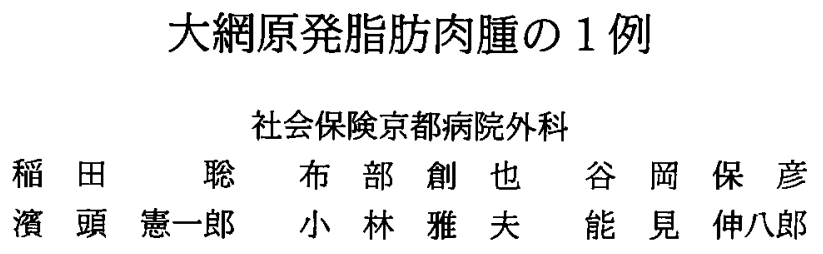

賓血と腹部腫瘤を主訴として極めて稀な大網原発脂肪肉腫の 1 切除例を経験したので 報告する.

症例は78歳女性，全身倇急感，食欲不振，腹部膨満を主訴として近医を受診した。血 液検查にて䆩血を，腹部超音波検査にて大きな腹腔内腫溜を指摘され，精查治療目的に 当院入院となった.CT, MRI, 腹部血管造影検査にて, 大網原発の腹腔内腫瘍と診断し, 平成11年 1 月 12 日全身麻酔下に腫湯摘出術を施行した。

腫湯は大網から発生する表面暗赤色, $27 \times 15 \times 10 \mathrm{~cm}$ 大の軟部腫瘍であったが，肝転 移, 腹膜播種は認めず, 病理診断では, 脱分化型脂肪肉腫であった。大網原発の脂肪肉 腫は予後不良な稀な肉腫であり, 本例も慎重に術後経過観察中である。

索引用語：大網腫湟, 脂肪肉腫

\section{はしめに}

脂肪肉腫は軟部腫瘍の中では比較的頻度の高い疾患 であり, 大腿, 臂部, 後腹膜に好発するが, 大網原発 症例は稀である。.今回著者らは大網原発脂肪肉腫の 1 切除例を経験したので, 若干の文献的考察を加えて報 告する.

$$
\text { 症例 }
$$

患者：78歳，女性.

主訴：全身倦急感, 食欲不振, 急激に増大した腹部 腫瘤触知.

家族歴：特記すべきことなし.

既往歴：特記すべきことなし.

現病歴：平成10年12月初旬に全身倦急感, 食欲不振, 腹部膨満感を認め近医受診した. 初診時の血液検查で 寊血, 腹部超音波検查で大きな腹腔内腫瘤を指摘され た. 平成 10 年 12 月 14 日精査治療目的にて当院入院とな った.

入院時身体所見 : 身長 $147 \mathrm{~cm}$, 体重 $56 \mathrm{~kg}$. 眼球結膜 に黄㾝なく, 眼瞼結膜に軽度賀血を認めた. 頸部, 鎖 骨上リンパ節は触知せず，胸部に異常所見は認められ なかったか゚，腹部は臍上部を中心として約 $20 \times 10 \mathrm{~cm}$ の弾性硬, 可動性のある境界明瞭な腫瘤を触知したが,

1999年12月 24 日受付 2000 年 3 月 1 日採用
圧痛はなかった。肝, 腎, 脾は触知せず, イレウス症 状も認めなかった。

入院時血液検查所見: $\mathrm{Hb} 7.4 \mathrm{~g} / \mathrm{dl}, \mathrm{Ht} 22.6 \%$ と高度 の貧血を認め, BUN は $24.9 \mathrm{mg} / \mathrm{dl}$ と上昇気味であっ たが, 肝機能検查は問題なく, CRP26.60mg/dl と著明 な上昇を認めた。また腫瘍マーカーは正常範囲内であ つた（表 1 ).

腹部超音波検查：腹部超音波検查では, 被膜を有し, 内部不均一で襄胞性部分と充実性部分を有する腫瘤を 認めた. 少量の腹水も認めた。肝腎膵は異常所見なく, 腫瘤本体は腹腔内にあるのが観察された。

腹部 CT 検查：肝門部から肝左葉外側区域, 胃前庭 部前面に接し，腹壁直下の腹腔内に23スライスにわた り約 $20 \times 10 \times 30 \mathrm{~cm}$ の腫瘤を認めた. 内部は不均一で 翇胞性部分と充実性部分を有する腫㢞であった。また

\section{表 1 入院時検查所見}

\begin{tabular}{|c|c|c|c|c|c|c|c|}
\hline LDH & 394 & IU/ & AMY & 82 & [U/ & WBC & $8530 / \mu 1$ \\
\hline GOT & 31 & IU/ & BUN & 24.9 & $\mathrm{mg} / \mathrm{dl}$ & RBC & $2.58 \times 10^{6} / \mu 1$ \\
\hline GPT & 25 & IUN & $\mathrm{Cr}$ & 1.2 & $\mathrm{mg} / \mathrm{dl}$ & $\mathrm{Hb}$ & $7.4 \mathrm{~g} / \mathrm{dl}$ \\
\hline ALP & 297 & IU/ & UA & 10.3 & $\mathrm{mg} / \mathrm{dl}$ & $\mathbf{H t}$ & 22.6 \\
\hline$\gamma$-GTP & 59 & $\mathrm{U} / \mathrm{I}$ & $\mathrm{Na}$ & 142 & $\mathrm{mEq} /$ & PLT & $369 \times 10^{3}$ \\
\hline TP & 6.6 & g/dl & $\mathbf{K}$ & 4.4 & $\mathrm{mEq} / 1$ & CEA & $0.9 \mathrm{ng} / \mathrm{ml}$ \\
\hline ALB & & $\mathrm{g} / \mathrm{dl}$ & $\mathrm{Cl}$ & 104 & $\mathrm{mEq} / 1$ & AFP & $5.1 \mathrm{ng} / \mathrm{ml}$ \\
\hline T-BL & 0.6 & $\mathrm{mg} / \mathrm{dl}$ & $\mathrm{Ca}$ & 4.3 & $\mathrm{mEq} / 1$ & CA19-9 & $10 \mathrm{U} / \mathrm{ml}$ \\
\hline D-BIL & 0.2 & $\mathrm{mg} / \mathrm{dl}$ & T-CHO & 204 & $\mathrm{mg} / \mathrm{dl}$ & & \\
\hline CRP & 26.60 & $\mathrm{mg} / \mathrm{dl}$ & FBS & 124 & $\mathrm{mg} / \mathrm{dl}$ & & \\
\hline
\end{tabular}


少量の腹水も認めた. 右胃大網動脈の拡張も認めた(図 1).

腹部 MRI 検査：CT と同様に内部不均一な腫瘤を 認めた．内部の低信号部位は出血が合併していると考 えられた（図2）。

腹部血管造影検査：腹腔動脈が根部でやや狭窄し， 頭側へ压排されている. 右胃大網動脈が拡張, 蛇行し, 尰禑のメインの栄養血管であると考えられた（図 3 ）. また晚期相では，胃前庭部右下方に約 $8 \times 12 \mathrm{~cm} の$ 腫 瘍䗅染像を認めた。上腸間膜動脈造影では，上腸間膜 動脈から分岐する中結腸動脈が尾側に圧排され，辺縁 動脈は腫湟の栄養血管であると考えられる。

注腸検查所見：横行結腸の尾側への壁外性圧排を認 めるのみであった（図 4).

以上より大網原発の腹腔内腫瘍とくに平滑筋肉腫や

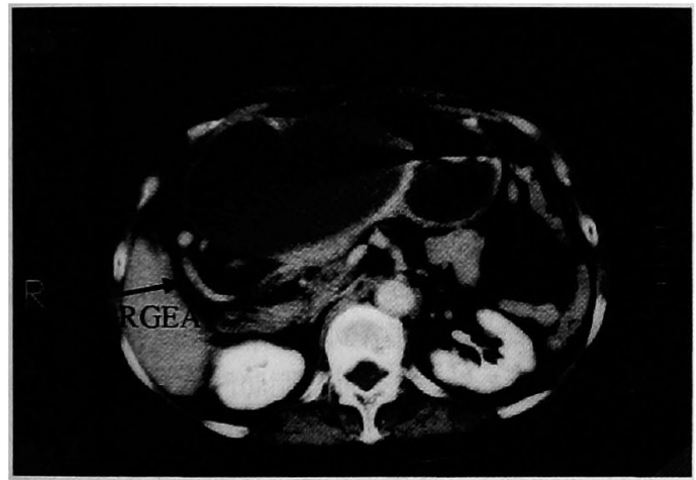

図 1 腹部造影 $\mathrm{CT}$ : 腹腔内に内部 low density な腫瘍を 認める。肝内側に右胃大網動脈の拡張が認められる。 RGEA：右胃大網動脈

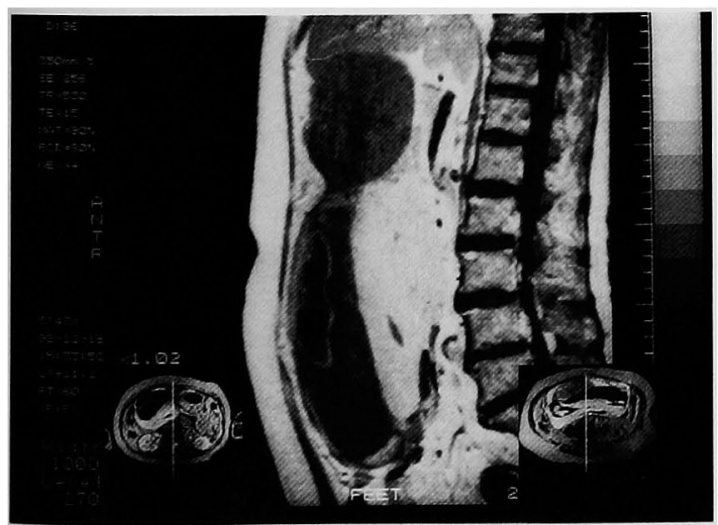

图 2 腹部 MRI（矢状断）：肝下面から腹腔内をほとんど 占めるような内部不均一な腫愓を認める。
間葉系由来の悪性腫湯と考え平成11年 1 月 12 日全身麻 醉下に開腹術を施行した。

術中所見：腫湟は大網の直上に胃大彎に接して存在

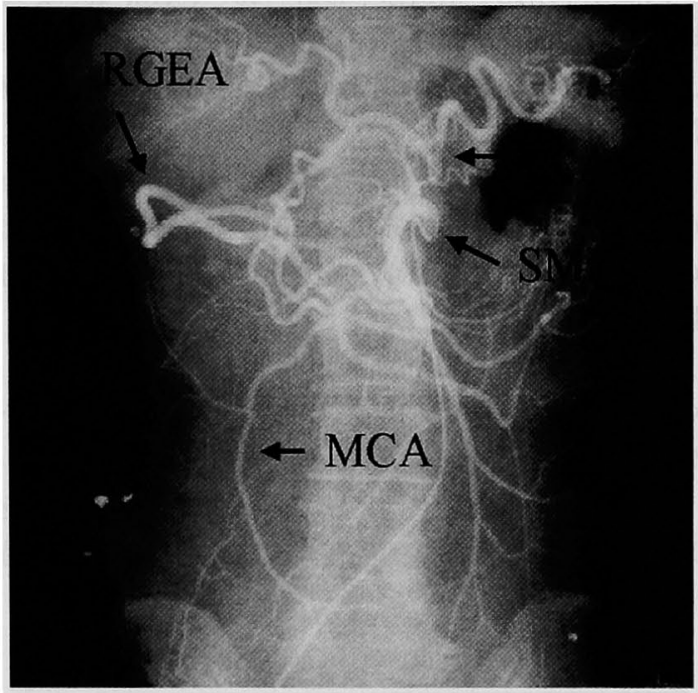

図 3 腹腔動脈造影：腹腔動脈は頭側に圧排され, 右胃大 網動脈は㹡張, 蛇行している.

RGEA：右胃大網動脈 CA：腹腔動脈

SMA：上腸間膜動脈 MCA：中結腸動脈

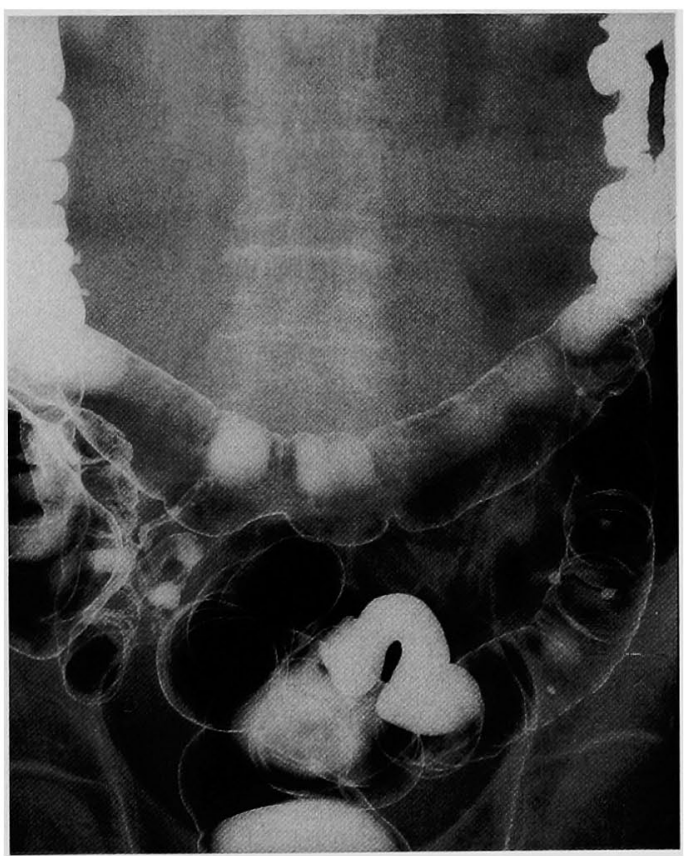

図 4 注腸検查：横行結腸が尾側に圧排されている。 
し, 腹膜, 肝, 胆琵, 胃と疻着していたが，直接浸潤 はなかった，右胃大網動脈が腫掦後面に走行し，腫瘍 に流入し,メインの栄責動脈と考え切離した. 肝転移, 腹膜播種，腹水は認めなかった。

摘出標本所見：指出標本は $27 \times 15 \times 10 \mathrm{~cm}, 1580 \mathrm{~g}$ の 暗赤色の表面平滑弾性軟な腫湯であった。割面は分葉 上であり，黄色を呈し，内部には铰胞状の部分を数個 認めた (図 5,6)。

病理組織検査所見：病理標本では spindle cell type の肉腫煬椂細胞が主であり，一部空胞を伴う脂肪分化 の認められる細胞を認め，脱分化型（混合型）脂肪肉 腫と診断した（図 7 )。

特殊染色では，actin，desmin 染色は陰性であり， vimentin 染色陽性, S-100弱陽性であり, 脂肪肉腫と一 致した。

術後経過：術後経過は良好であり，合併症なく術後 15日目に退院となった。現在術後11力月再発なく経過 している.

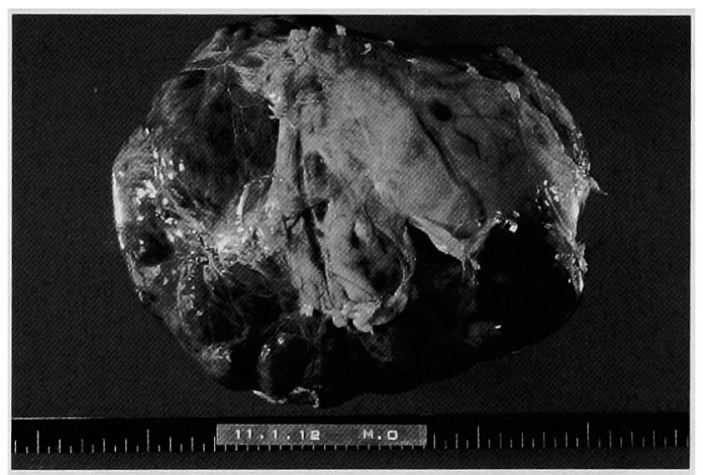

図 5 摘出標本：暗赤色な弾性硬の腫瘍である. $27 \times 15 \times 10 \mathrm{~cm}, 1580 \mathrm{~g}$.

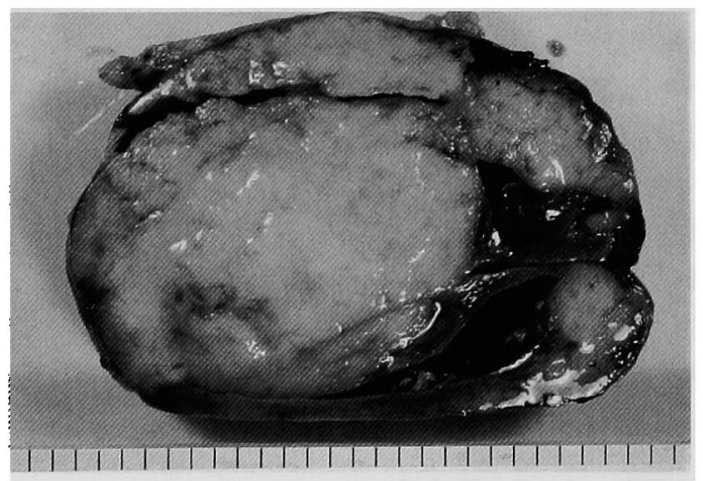

図 6 割面像：充実性部分は黄色の軟部腫煌であった。
考 察

脂肪肉腫は稀な疾患であるが，軟部悪性腫瘍の中で は 5 〜0\%をしめ, 比較的頻度の高い疾㭧である ${ }^{1}$. 好 発部位は, 驾部, 大腿, 後腹膜であり, 大網, 腸間膜 に発生する事は極めて稀である。

大網悪性腫湯の大半は転移性であるが, 原発性の腫 瘍の中では，平滑筇由来のものが最も多い. 本邦での 大網脂肪肉腫の報告は㭘索し得た限りではわずか15例 であった2゙

脂肪肉腫の好発年齢は50〜60歳台であり，男女間の 頻度に差はなく，検索し得た15例の大網原発脂肪肉腫 では，17 83歳で平均年齢は56歳，女性 10 例，男性 5 例であった。

初発症状として, 特徵的なものはなく, 腫瘍が増大 してからの腫瘤触知や腹満感が多い。本症例のように, 腫瘍内出血による腫湯の急激な増大と筫血で発見され る例は他に報告がない。

診断には，腹部超音波検査，CT, MRI, 腹部血管造 影検査などが行われる．超音波検查やCT や MRIで は存在診断や病変の広がりを診断するのには有用であ るが，質的診断や原発部位を特定するのは難しい，血 管造影検查で血管の拡張，不整像や腫晹濃染像など により原発部位は推測されるが8)，質的な診断は非常 に難しい．術前に超音波下の穿刺細胞診で脂肪肉腫と 診断した(例4もあるが，術前に脂肪肉腫と診断した例 はほとんどなく，大網原発の悪性腫湟として手術され ている. 本症例も，腹腔内腫瘍で大網原発の悪性腫瘍 を疑い手術を施行した。

脂肪肉腫の治療は外科的切除がまず第一選択であ

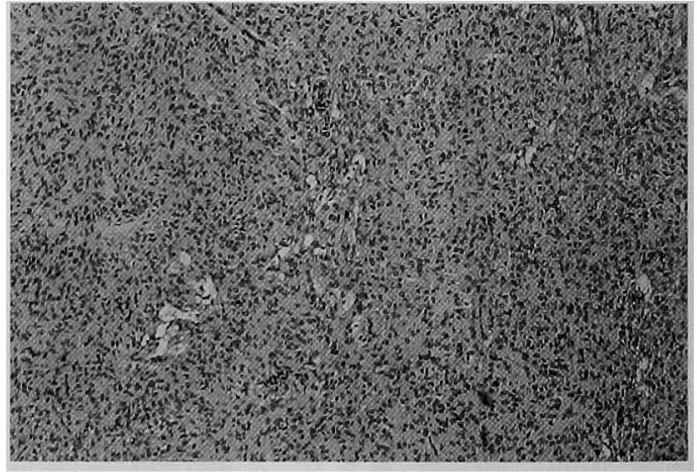

図 7 病理標本像 (HE 染色) : spindle cell type の肉腫 細胞がメインであるが，一部空胞を伴う脂肪分化が認 められる. 
る.一般的に脂肪肉腫は被膜外浸潤を示す事が多く， 単純切除では局所再発が多いため, 拡大切除が必要で あり，記載のある症例では，5例に他葴器合併切除が 行われている. 一方開腹時にすでに進行している場合 があり，4 例で腹膜播種，多発肝転移，遠隔転移がそ れぞれ 1 例ずつ認められた。脂肪肉腫は組織型によっ ては放射線感受性が高いとされるが9，四肢の場合と 異なり，大網原発の例は腸管などへの影響のため，い ずれの症例でも放射線治療は施行されていない，化学 療法も腹膜播種や, 肝転移の症例で施行されているが, いずれも早期に死亡しており効果は期待できない. 今回の症例は外科手術のみで経過観察中である.

脂肪肉腫はWHO 分類で高分化型 (well differentiated type), 粘液型 (myxoid type), 円形細胞型 (round cell type), 多形型 (pleomorphic type), 混 合型 (脱分化型) (mixed type, dedifferentiated type) に分けられるが，予後は組織型によって大きく左右さ れる.

Enzinger $ら^{10}$ によると通常の脂肪肉腫の 5 年生存 率は，高分化型85\%，粘夜型77\%，と良好であるが， 円形細胞型 $21 \%$, 多形型 $18 \%$ と非常に悪い. 本邦での 大網脂肪肉腫の症例で記載のあったものでは, 高分化 型 1 例, 粘液型 4 例, 円形細胞型 2 例, 多形型 1 例, 混合型 3 例, 高分化型優位で円形型, 多形型の混在す るもの 1 例であった。一方大網脂肪肉腫の場合, 高分 化型の 1 例にも腹膜播種例が報告されており，粘液型 の2 例のも同样に腹膜播種例があり早期に死亡してい る. 本邦での検索 15 例の最長生存例が現在 12 力 月であ り，長期の予後については不明である.
結 語

われわれは稀な大網原発の巨大脂肪肉腫を経験した ので，文献的考察とともに報告した。

文 献

1）松本 黙, 中泉治雄, 品川 諴他: 大網原発の巨 大脂肪肉腫の 1 例。消外 $17: 1513-1519,1994$

2）相田芳夫，小尾芳郎，增沢成幸他：大網加ら発生 したと考えられる脂肪肉腫の 1 例. 共済医報 $39: 550-555,1990$

3）井原慎司, 曽我俊彦, 加藤 仁他：腹水中に腫晹 細胞が出現した大網原発脂肪肉腫の 1 例. 中勢病 誌 $9: 111-112,1988$

4) 小澤正則, 落合浩平, 藤田正弘他：大網脂肪肉腫 の 1 例, 癌の臨 $38: 91-97,1992$

5）佐々木恵子, 小西二三男, 松能久雄他：大網の脱 分化型脂肪肉腫の 1 例。病院病理 $11: 169,1992$

6）山口紀子, 伊藤 勇, 野崎泰宏他: 大網原発の多 形型脂肪肉腫の 1 例. 日臨外会誌 $59: 2921-$ 2925, 1998

7) 竹長真紀, 荻野充利: 大網原発脂肪肉腫の 1 例. 日臨外会誌 60，201-204，1999

8）岸川 高：大網動脈造影の診断的価値一大網血管 の拡張・堌生の意着について一。目医放線会誌 $39: 467-481,1979$

9) Perry $\mathrm{H}, \mathrm{Chu} \mathrm{FCH}$ : Radiation therapy in the palliative management of soft tissue sarcoma. Cancer $15: 179-183,1962$

10) Enzinger FM, Winslow DJ : Liposarcoma. A study of 103 cases. Virchows Arch Pathol Anat $335: 367-388,1962$ 


\title{
A CASE OF LIPOSARCOMA OF THE GREATER OMENTUM
}

\author{
Satoshi INADA, Soya NUNOBE, Yasuhiko TANIOKA, Kenichiro HAMAGASHIRA, \\ Masao KOBAYASHI and Shinpachiro NOMI \\ Department of Surgery, Social Insurance Kyoto Hospital
}

We report an extremely rare case of primary liposarcoma of the greater omentum in a patient complaining of anemia and an abdominal tumor.

A 78-year-old woman with anemia was seen at the hospital because of general fatigue, poor appetite and abdominal distension. Abdominal ultrasonography showed a large abdominal mass. CT scan and magnetic resonance imaging presented a large heterogenous tumor in the abdomen. Angiography revealed that the right gastroepiploic artery might be a main feeding artery of the tumor.

The patient was diagnosed as having a sarcoma of the greater omentum and operated on. The tumor measuring $27 \times 15 \mathrm{~cm}$ situated on the greater omentum, neither invasion nor metastasis was seen to the adjacent organs.

The histopathological examination concluded that the huge tumor of the greater omentum was liposarcoma, dedifferentiated type. Liposarcoma of the greater omentum is a rare disease with a poor prognosis. The patient is strictly followed up in the clinic, as of 11 months after the operation. 